\title{
Erring from Good Huswifry? The Author as Witness in Margaret Cavendish and Mary Trye
}

\author{
ISABELLE CLAIRHOUT
}

Ghent University

\begin{abstract}
Margaret Cavendish and Mary Trye differ in the extent to which their scientific ideas and social positions allowed them to translate their view of the embodied observer into a steady textual image that was consistent with their methodological and epistemological ideas. However, they are united in a rhetoric of opposition that accommodates their defence against accusations that females had no authority in these matters due to inferior physical and mental qualities (although Cavendish's defence is far from unequivocal). Moreover, both took on the role of a spokesperson for a member of their family and, again, their interpretation of that role is affected by their scientific views. This article will examine the similarities and differences of their authorial self-fashioning in the context of what was far from homogeneous early modern scientific authorship.
\end{abstract}

Margaret Cavendish et Mary Trye diffèrent dans la mesure dans laquelle leurs idées scientifiques et leurs positions sociales les autorisaient à traduire leur vues de observateur incarné en une image textuelle non seulement constante mais en accord avec leurs idées méthodologiques et épistémologiques. Elles sont toutefois unies par une rhétorique de l’opposition s'adaptant à leur défense contre des accusations affirmant que les femmes navaient aucune autorité en la matière en raison de leurs qualités physiques et mentales réduites (bien que la défense de Cavendish soit loin dêtre sans équivoque). De plus, toutes deux ont adopté le rôle de porte-parole pour un membre de leur famille et, encore une fois, leur interprétation de ce rôle est affecté par leurs vues scientifiques. Cet article examinera les similarités et différences de leur positionnement auctorial dans un contexte loin de l'homogénéité auctoriale scientifique de la période des débuts de lère moderne.

\section{Introduction}

$\mathrm{W}$ hen Mary Trye wrote in her Medicatrix (1675) that it was not uncommon to find women in print, her claim was justified: in the late seventeenth century an increasing number of women were open about the fact that they wrote with a view to having their work published. ${ }^{1}$ Literary translations

1. See Marcy L. North, "Women, the Material Book and Early Printing," in The Cambridge Companion to Early Modern Women's Writing, ed. Laura Lunger Knoppers (Cambridge: Cambridge University Press, 
or religiously inspired self-reflexive texts were seen as relatively safe for female writers at the time, although there were also women who tried other pathssuch as Anne Conway, Katherine Philips, and Aphra Behn, each of whom claimed a distinctive authorial voice. Two women who tried the less formulated paths were Margaret Cavendish and Mary Trye, who decided to engage in natural philosophical and medical debate respectively.

These women found themselves in an intellectual climate which has generally been considered to be dominated by a "New Science"2 that was trying to propagate a new methodology and epistemology that depended more explicitly on perceptual observations and individual experience, replacing an Aristotelian concept of experience as generally accepted knowledge. In institutionalized scientific communities, rhetoric based on ancient theories and authority was increasingly considered obsolete. Moreover, sense observation was often standardized into physical experiment, the phenomena of which had to be observed by at least two eye witnesses. Steven Shapin and Simon Schaffer describe these witnesses as "authoritative persons" publicly validating what they observe, which can then be accepted as scientific knowledge, as "fact," and which becomes a kind of shared, collective knowledge. ${ }^{3}$ In the case of the Royal Society, these witnesses were the Fellows conversing with each other, and "authoritative" implied they should be men of a certain social status who were considered to have high moral standards and to be knowledgeable. ${ }^{4}$ The witnesses who bore up the New Science found their textual ally in the print medium,

2009). North writes that “[i]n most years from 1545 on, a buyer at a London bookseller's stall would have found one or more publications attributed to a woman [...]. The numbers of women authors in print do not come close to those of male authors, but women were conspicuous enough in early print to make female authorship a relatively familiar, even conventional, phenomenon" (p. 68). For the increasing number of technical works by women, see Elizabeth Tebeaux, "Women and Technical Writing, 1475-1700: Technology, Literacy and Development of a Genre," in Women, Science and Medicine, 1500-1700: Mothers and Sisters of the Royal Society, ed. Lynette Hunter and Sarah Hutton (Stroud: Sutton, 1997), pp. $29-62$.

2. Since the terms "science" and "scientific" have always been rather problematic in an early modern context, it is difficult to find a practically usable term that does not carry the connotations it received in the nineteenth century. I shall opt for the pragmatic solution and warn the reader that any use of these terms should be seen as a rather vague and undefined reference to intellectual work, philosophical exercises, and also the more practical day-to-day foundations of home remedies.

3. Steven Shapin and Simon Schaffer, Leviathan and the Air-Pump: Hobbes, Boyle, and the Experimental Life (1985; Princeton: Princeton University Press, 2011), pp. 26, 281-82, 336.

4. Shapin and Schaffer, p. 56. 
which was increasingly being used for the dissemination of ideas and, consequently, the consolidation of theories..$^{5}$ In print, authors could communicate to a wider audience their role as a physical witness, and in that capacity they became intermediate textual witnesses. ${ }^{6}$ This sharing of eyewitness accounts turned not only the author but also the reader into a witness, thus maximizing the validation and spread of knowledge. ${ }^{7}$

However, the methodology and epistemology as championed by the Royal Society were not as generally acknowledged as one might think. ${ }^{8}$ First of all, the terms "experience" and "observation" could be interpreted in very different ways, and the empiricism that these terms have come to describe could, according to Charles T. Wolfe, denote an experimentalist empiricism, a moral/ practical empiricism, or a "medically motivated, 'embodied' empiricism" that relied more on medical practice and observation than experiment. ${ }^{9}$ It is especially in the context of this last kind of empiricism that I shall examine Mary Trye, her medical practice, and her authorship. Secondly, as we shall see in discussing Cavendish, an emphasis on observation did not necessarily endorse an empirical epistemology.

The increasing influence of a very diverse empiricism necessarily has repercussions for the ways in which Trye and Cavendish asserted their authority as writers. Shapin and Schaffer's definition of the witness does not necessarily agree with Trye's or Cavendish's self-representation as writing observers, especially since they were barred from official institutions and scientific academies. Nevertheless, I shall use the term "witness" in my examination of these women. As will become clear, they had contrasting ideas about the "making"

5. For the relations between science, literature, and rhetoric, see Juliet Cummins and David Burchell, eds., Science, Literature and Rhetoric in Early Modern England (Aldershot: Ashgate, 2007); Alan Salter, "Early Modern Empiricism and the Discourse of the Senses," in The Body as Object and Instrument of Knowledge: Embodied Empiricism in Early Modern Science, ed. Charles T. Wolfe and Ofer Gal, Studies in History and Philosophy of Science 25 (Dordrecht: Springer, 2010), pp. 59-74.

6. This is what Shapin and Schaffer call the "virtual witness" (p. 60).

7. Shapin and Schaffer, p. 63.

8. Eve Keller explains Cavendish's deviation from the Royal Society's stance in the context of a more general scepticism of the Society's work. See Eve Keller, "Producing Petty Gods: Margaret Cavendish's Critique of Experimental Science," ELH 64, no. 2 (1997), p. 450.

9. Charles T. Wolfe, "Empiricist Heresies in Early Modern Medical Thought," in The Body as Object and Instrument of Knowledge, pp. 333-44. 
of knowledge and what a witness constituted. As a Helmontian practitioner of chemical medicine, Trye engaged in polemical medical debate that focused on the body. Her unproblematic interpretation of the physical body as an object to be studied and as an instrument for observation is reflected in her defence of experience and experiment, and her self-fashioning as observer, author, and daughter of a chemical physician. Subsequently, when discussing Cavendish's less unequivocal view of the body and its potential for the attainment of knowledge, we shall see that her ambiguous relation with observation, housewifery, and experiment also partly formed a framework for her representation of her husband. Finally, I hope to illustrate that as these women asserted themselves in association with a male member of the family, their discourse displays more similarities than is generally acknowledged. An increase in debate about body and knowledge united Cavendish and Trye in a rhetoric of opposition that shaped their defence against accusations that inferior physical and mental qualities denied females any authority in intellectual matters.

\section{Mary Trye: "experientia docet"}

Mary Trye developed a self-image in her Medicatrix, or the Woman-Physician (1675) that engaged with scientific and medical developments in late seventeenth-century England. Warning readers of the dangers and indirections of rhetoric, Trye herself proceeded to deploy rhetorical devices to construct her role of empirical witness in support of her father's and her own medical practice. By doing so she defined her attitudes towards the new "chemical medicine" and, by extension, the Royal Society.

Unfortunately, little biographical or archival information about Trye has been uncovered. ${ }^{10}$ Her father has been treated more kindly by history. Thomas

10. One copy of Medicatrix in the Wellcome Library contains an inscription on the fly-leaf by James Crossley, who claimed that "Of this very rare and most curious Book I never saw or heard of any other copy than this which is corrected in the hand writing of Mrs Trye herself." The annotations are sparse and, to my knowledge, there are no surviving letters to compare the hand with. Nevertheless, there is reason to believe that the annotations were indeed made by Mary Trye herself, or at least someone closely involved in the publication, due to the fact that Crossley is a reliable source and the supposition that a false attribution to Trye would not add much to the value of this book, since she was not particularly sought after. I am indebted to Dr. Richard Aspin, head of Research and Scholarship at the Wellcome Library, for providing me with information on the authenticity of these annotations and Crossley's claim. 
O'Dowde, trained as an apothecary, was a medical practitioner and courtier. ${ }^{11}$ According to his daughter, he
descended from a Generous Family, and [was] Heir to no less Fortune in the Kingdom of Ireland, but his Fathers Death leaving him in Minority, and subject to the injury and misfortune, the Second Marriage of his Mother contracted, and after the Distraction and Troubles in that Nation compleated, he was by this means deprived of the greatest part of his Right and Inheritance, a damage not inconsiderable. ${ }^{12}$

Trye recounts how, after the execution of Charles I, her father was imprisoned several times and eventually banished. He became groom to the bedchamber of Charles II after his return to London and published a broadside entitled The Poor Man's Physician, which was then developed into a larger work of more than 100 pages. ${ }^{13}$ O'Dowde also led an attempt to attain a royal charter for a new anti-Galenic, Helmontian-inspired medical institution called the "Society of Chemical Physicians," but despite sympathy from the court, he was unable to acquire one and was accused of "quackery and political subversion."14 Ultimately, he died in the Plague of 1665-according to Trye, not because he could not cure the illness himself but because his relentless efforts to cure others from this rampant disease caused him to neglect his own health (57-58).

Almost everything we know about Trye has been derived from her Medicatrix. There she states that she had recently returned to London (in October 1674) and that she had "continued [her father's] Medicines to this day,

11. O'Dowde had been in the service of Charles I, as well as Charles II. See Harold J. Cook, “The Society of Chemical Physicians, the New Philosophy, and the Restoration Court," Bulletin of the History of Medicine 61, no. 1 (1987), pp. 61-77. Cook described O’Dowde as one of the "self-taught empirics who dressed their remedies in the garb of chemistry" (p. 72).

12. Mary Trye, Medicatrix: or The Woman-Physician (London: Printed by T. R. and N. T. and Sold by Henry Broome, 1675), pp. 25-26. All subsequent quotations are taken from this edition. Page numbers will follow in parentheses in the main text.

13. Thomas O'Dowde, The Poor Man's Physician: Or the True Art of Medicine, As it is Chymically prepared and administred, for healing the several Diseases incident to Mankind, $3^{\text {rd }}$ edition (London: F. Smith, 1665).

14. For more information on the Society of Chemical Physicians, see Cook, "The Society of Chemical Physicians," pp. 62-63. 
(though not in this City)" (Epistle Dedicatory, A3r). Trye was thus professionally active in "chemical medicine," and called herself a chemical physician. In her Medicatrix she claims that she has "had Twelve years Experience" and is confident that in that time she has seen cases that "the Physician at Warwick [...] in all his Practice never saw" (106). These chemical physicians were often called "iatrochemists" in the Paracelsian tradition. Many physicians at the time, and other medical practitioners for that matter, were attracted to the Paracelsian chemical philosophy, which claimed to transform the heathen Aristotelian and Galenic theory of the four elements into a Christian, chemical system based on the tria prima: everything that constituted the macro- and microcosm was reducible to salt, sulphur, and mercury. ${ }^{15}$

Allen G. Debus explains that "later iatrochemists, finding little convincing proof for either system, felt free to utilize the four elements and the three principles as they saw fit." ${ }^{16}$ Indeed, Mary Trye herself seems to have adapted her medical theory of medicines and disease according to her own views and the situation of the medical market. She was, after all, also commercially involved at a time when medicine was increasingly being commodified. ${ }^{17}$ Although at first she might appear as an anti-traditionalist in her vehement attacks against ancient learning, the textual tradition, and everything Galenic, she proves to be more nuanced and pragmatic than that. For consumption, "which is a Disease many Physicians [...] endeavour to cure [...] by administring Nutriment and Restoratives before the Flux of Humours be prevented, and the fixed matter removed," she recommends "A Pulmonick Essence, a Pectoral Electuary, a Cleansing\&Coroboroting [sic] Extract, Balsamick Drops: By which Medicines the cause of those salt, sharp, fretting humours will be attempered and dislodged;

15. Allen G. Debus explains: "Although the theory of the tria prima was a modification of earlier theories, it has a special significance in the rise of modern science. Clearly part of an attack on Scholastic philosophy, the introduction of the new principles also led to considerable confusion." See Allen G. Debus, The Chemical Philosophy (Mineola: Dover publications, 2002), p. 78.

16. Debus, p. 79.

17. Trye was not exceptional as a female practitioner. For more information on early modern women and medical practice, see Leigh Whaley, Women and the Practice of Medical Care in Early Modern Europe, 1400-1800 (Basingstoke: Palgrave Macmillan, 2011); Monica Green, Making Women's Medicine Masculine: The Rise of Male Authority in Pre-modern Gynaecology (Oxford: Oxford University Press, 2008); Mark S. R. Jenner and Patrick Wallis, Medicine and the Market in England and its Colonies, c. 1450-c.1850 (Basingstoke: Palgrave Macmillan, 2007); Elaine Hobby, Virtue of Necessity: English Women's Writing 1649-88 (Ann Arbor: University of Michigan Press, 1988), pp. 165-89. 
the Phlegmatick, and Corosive Matter digested and removed" (An Advertisement, n.p.). As can be seen in her appraisal of her medicines, her theoretical background still incorporates much of the old humoral theory and thus resembles many medical works aimed at a public between university-educated professional and unlettered layman. If medicines that expel an excess of humours are what the people want, then Trye will make sure she can provide them. Nevertheless, chemical physicians increasingly focused on disease as being caused by external factors, rather than on an internal imbalance of humours. All of this led these "chemists" to adopt a rhetoric that opposed Galenic medicine, as they turned to observation and experience.

So Mary Trye adopted the same rhetoric of opposition and observation. This is not surprising, as her book was conceived as a vindication of chemical medicine and a defence of Trye's father against the attacks of Henry Stubbe. ${ }^{18}$ Stubbe, the antagonist in her work, was originally a parliamentarian, but had obtained the office of king's physician to Jamaica after the Restoration. ${ }^{19} \mathrm{He}$ appears to have been keen on seeking controversy, and vehemently attacked the Royal Society and its members (among them Thomas O'Dowde) in his work Campanella Revived, Or an Enquiry into the History of the Royal Society, whether the Virtuosi there do not pursue the Projects of Campanella for the reducing of England into Popery (London, 1670). ${ }^{20}$ But Trye strikes back: people might believe his slanderous words, she says, because they like to "follow tradition like their Tutor the Verbalist" (79)—the Verbalist being Stubbe himself. Trye reproaches Stubbe with being a mere follower of tradition-a man of words, not deeds-and scoffs that his words are as useless as his pet subject phlebotomy is in curing diseases. ${ }^{21}$ Stubbe was also very sceptical of the Fellows' use of instruments, claiming that since our eyes are already deceivable (despite their being

18. Stubbe was a friend of Thomas Hobbes's (who was himself a royalist).

19. Mordechai Feingold, "Stubbe, Henry (1632-1676)," in Oxford Dictionary of National Biography (Oxford: Oxford University Press, 2008), online ed., accessed 28 Sept 2012, http://dx.doi.org/10.1093/ ref:odnb/26734.

20. For more information on Trye's royalist and religious background and associations, as well as the politics of medicine, see Stanton J. Linden, "Mrs Mary Trye, Medicatrix: Chemistry and Controversy in Restoration England," Women's Writing 1, no. 3 (1994), pp. 341-53.

21. Stubbe published An Epistolary Discourse concerning Phlebotomy in 1671. With Harvey's discovery of systemic blood circulation finding more and more acceptance, bloodletting, which was based on humoral theory, began to be considered useless in most cases. 
"telescopes of God Almighty's making"), man-made instruments surely are even more unreliable. ${ }^{22}$ Cavendish, as will be seen shortly, held similar views.

Trye's iatrochemical discourse was mostly influenced by the Flemish physician Jan Baptist Van Helmont, who had a high regard for, but was also critical of, Paracelsus. Van Helmont believed that the essence of life was to be found in the blood, which explains his dismissal of bloodletting, and thus also Trye's aversion to it. Van Helmont corroborated his views on the three principles with experiments such as the weighing of the earth in which a tree had grown to prove that it is water alone, and not the element of earth that contributes to the formation of the tree. ${ }^{23}$ It is in this context that we should see Trye's defence of experiment. As for Van Helmont's view of the diseased body, he maintained that disease is not caused by a catarrh flowing from the brain to the rest of the body. Instead, he argued that the body hosted vital principles, or archei, which were disturbed by external irritants in case of disease. ${ }^{24}$ This also forms a basis for Trye's anti-Galenic sentiments, since Galenic nosology was focused on the body's intrinsic humoral imbalances.

Although they were fighting a losing battle, Helmontian-inspired physicians and their rhetoric reflected the growing influence of empiricism. ${ }^{25}$ Trye's language of opposition was thus also connected with her rhetoric of experience and experiment. Although she does not propose a systematic empirical epistemology and never goes into a semantic discussion of what experience or experiment means to her, from her emphasis on treatment we can conclude that "experience" refers in her view to medical practice, while "experiment" in her discourse seems to have the connotation of a more formal comparison in medical practice. Her strong belief in (undefined) trial and experiment was based on a Helmontian tradition and motivated her to actively challenge traditional Galenic practitioners. Thus Trye claims that Stubbe is no match for her because she is more experienced and has superior medicines at her disposal.

22. Henry Stubbe, The Plus Ultra reduced to a non Plus (1670), pp. 40-41, quoted in Simon Schaffer, "Regeneration: the Body of Natural Philosophers in Restoration England," in Science Incarnate: Historical Embodiments of Natural Knowledge, ed. Stephen Shapin and Christopher Lawrence (Chicago: University of Chicago Press, 1998), p. 89.

23. See Debus, pp. 318-19.

24. Debus, pp. 360-61.

25. Debus notes that "The concept of acid-base neutralization, so important for the development of chemistry later in the century, derives principally from van Helmont" (p. 371). 
Many Helmontians challenged their opponents, but no trials were ever executed. ${ }^{26}$ For every patient that Stubbe cures of smallpox by phlebotomy, Trye will cure two, she says, and without the painful and dangerous practice of bleeding:

For I do hereby take liberty to tell Mr. Henry Stubbe a Physician at Warwick, That I will Cure the Disease of the Small Pox with him without Phlebotomy, or taking one drop of Blood from the Patient: and I will Cure the patient with that safety and advantage, I have before set down; and more, that my Antagonist may have no objection, I will not say Ten; but I will Cure two for one with him in this Disease; that is I will Cure two Patients of the Small Pox by my Method and Medicines, without Phlebotomy, for his one that he shall Cure by Phlebotomy and his Method; and if he desires it, I will give him greater odds yet, rather then [sic] decline the Trial. $(107)^{27}$

Continuing in the same vein, she criticizes him for having no practical knowledge and for instead relying all too much on traditional texts; he "runs away to his Authors, to tell what they did a Thousand years ago" (108).$^{28}$ Trye's emphasis on experience and experiment rather points to her faith in progress in the practice of hands-on medicine, and, in an allusion to Stubbe's calling upon Johannes Anglicus and Gilbertus Anglicus as witnesses to the use of phlebotomy in smallpox, she states that "what English John and Gilbert did Hundreds of years ago, or any other Authors in those cases, was because they knew no better" (104). Since then, medicine has evolved beyond dangerous and unnecessary blood-letting, and ignorance has been driven out now that better (chemical)

26. Andrew Wear, Knowledge and Practice in English Medicine, 1550-1680 (Cambridge: Cambridge University Press, 2000), p. 385.

27. Also quoted in Wear, p. 385. This sounds remarkably like what Van Helmont himself proclaimed in "respondet author" (sect 9), Ortus Medicinae, pp. 526-27: "Let us take out of the hospitals, out of the Camps, or from elsewhere, 200, or 500 poor People, that have Fevers, Pleurisies, \&c. Let us divide them into halfes, let us cast lots, that one halfe of them may fall to my share, and the others to yours; [...] we shall see how many Funerals both of us shall have." Quoted in Debus, p. 377.

28. Stubbe claimed that if the Fellows of the Royal Society would read more they would realize that what they did has already been done: "I am blamed for diminishing the glory of our Nation, by ascribing all discoveries to the Antients, or else to Foreigners: to which I answer, that they take off from the glory of our Nation more, who usurp the inventions of others. [...] neither do I lessen the performances of the Honourable and curious Mr. R. Boyle, when I averr [sic] that Aristotle did hold the Ayre to be ponderous, and weighed it before him" (Campanella, "To the Reader," n.p.). 
remedies are available, says Trye. Unsurprisingly, as the advertisement at the end of Medicatrix illustrates, these are remedies she also sells.

Regardless of her reproach that Stubbe is all words and no deeds, and her disapproval of his all-too-great reliance on ancient authorities (he follows "a Path [...] well trodden," 93), Trye clearly uses rhetoric to defend her own position as an author. Her crucial statement that "[ $\mathrm{t}] \mathrm{his}$ is an age that believes no Authors, nor any Medicines, but what are seen and known to be true, and justified by Fact" (100) proposes the participating witness/observer as the redeemer of textual communication as long as he or she is also the originator of these texts. Despite her proclaimed distrust of verbiage and her claim that "A man may read an Author, and yet not understand a Medicine" (74), she acknowledges the importance of reading, writing, and learning in general, albeit as a preparation for real medicine: "Authors I conceive direct and instruct their Students, only by pointing out the Way, not by walking to the Journeys end" (74). Books may set one on the right track, but along the way only experience and practice will make a true chemical practitioner. Trye finds Stubbe incompetent as a physician, and she points to his old-fashioned belief in bloodletting as proof. Consequently, Stubbe does not deserve to be called "author": "where are his famous works extant, and victorious Books exposed to Sale? For I am inform'd, the Author himself, with most Book-sellers in this City, is not known" (14). Others seem to agree, she suggests, for he is not being read at all. Contrary to what her sneers at Stubbe's reliance on textbooks suggest, this implies that Trye values the importance of authors and authoritative texts, provided that they are based on experience. Only a good medical practitioner can be a good medical author. Stubbe has no right to write, since, according to Trye, he has not earned the title of authoritative writer through practice in the field, and through published output. ${ }^{29}$

So her emphasis on physical, sensory experience and practice does not lead her to reject authorship, nor readership. Instead, authorship becomes the vehicle that allows a physical, empirical witness to share an experience with

29. Trye perhaps ironically claims that she regrets not having had the time yet to "see any of their [the Fellows'] writings" (p. 83), because she is so consumed by her medical practice. In spite of her busy professional life, she claims that she has been able to read Plutarch, thus demonstrating that she is wellread, even interlarding the text with Latin and French proverbs in a subtle display of erudition. For example, Trye notes that "[1] earning is abused, [...] and by this means the Proverb will be truly verified, Il vaut mieux tomber entre les mains d'un Medecin heureux, que d'un Medecin Scavant" (p. 92). 
readers (and potential customer-patients) who validate the witness herself. Trye thus inscribes herself as an author within a written medical tradition. This is very much in keeping with contemporary developments in science, which saw an increasing written (and printed) interactive communication between players in the scientific field. Trye sought to connect with a group of medical practitioners at a time when group identification and communication became crucial for the validation of knowledge. Although no regular player herself, Trye realizes that the value of practical experience can be asserted by means of words and the print medium, as long as one remains alert to the pitfalls of rhetoric and as long as practice and experience remain central. It is clear that her attitude towards tradition and authorship is a very ambiguous one, but she is goaded onwards by her urge to defend her father and his "chemical medicine."

Since Medicatrix is mainly presented as a defence of Trye's father, this of course influences her persona. Mary Trye explicitly defines herself as the daughter of a well-known chemical physician, both by always referring to O'Dowde as "my father" and by stating that upholding her father's honour is her duty: "I was resolved none should answer for him but myself being the only child of this injurd chymical physician" (Epistle Dedicatory, n.p.). The authorial representation of a father-daughter relationship was in fact a common trope in "chemical medicine" and alchemy. ${ }^{30}$ However, in defending her father against Stubbe's attacks, we find that she is actually also defending herself by taking on the role of an empirical, physical, and necessarily biologicallydetermined witness. Strengthening the more natural link between herself and this renowned medical practitioner, Trye emphasizes the biological nature of the connection in a medical environment that claims to focus on empirical observation and physical experience. She finally defines herself as one of the "Successors of O'Dowde," who "gainsay and object against the ignorant Malpractice of Stubbe" (126). The term "successor" incorporates the notion of

30. See, for instance, Dorothea Heitsch, "Cats on a Windowsill: An Alchemical Study of Marie de Gournay," in Gender and Scientific Discourse in Early Modern Culture, ed. Kathleen P. Long (Aldershot: Ashgate, 2010), pp. 217-38; Penny Bayer, "Madame de la Martinville, Quercitan's Daughter and the Philosopher's Stone: Manuscript Representations of Women Alchemists," in Gender and Scientific Discourse in Early Modern Culture, pp. 165-90. Patricia Crawford notes that many women who advertised their medical skills referred to the fact that they were taught by a husband or father; see "Printed Advertisements for Women Medical Practitioners in London, 1670-1710," The Society for the Social History of Medicine Bulletin 35 (1984), p. 67. 
being the intellectual successor, but also of being the natural heir to a certain post, which implies that she is biologically and legitimately connected to her predecessor. It also implies that she is now part of a practical, medical tradition in a very physical way. Moreover, as O'Dowde's daughter, she was in a privileged position that allowed her to observe and learn from him while assisting in his medical profession. Trye explicitly states that her father taught her everything she knows and consequently derives at least part of her authority as a writer from him. In that sense, she acted as an affirmation of his work and its value. After his death, she became a witness in the sense both of a spokesperson and of an active practitioner who embodied her father's medical philosophy.

\section{Margaret Cavendish: undermining the physical witness?}

Margaret Cavendish's authorial representation and her position in the natural philosophical debate were much less straightforward than Trye's. Despite or perhaps because so much biographical information and so much of her own philosophical writing are known to us, she is much harder to pin down as an author as well as an observer or witness.

Margaret Cavendish, Duchess of Newcastle, was born as Margaret Lucas in 1623, as the youngest daughter of Elizabeth Leighton and Thomas Lucas of Colchester. Her father died in 1625, after which, as Anna Battigelli has described, the Essex-based family was capably cared for by her mother, "though psychologically she created an insular family environment that had lasting and not entirely positive consequences for the formation of her daughter's character." ${ }^{31}$ The royalist Lucas house was ransacked by parliamentarian troops in 1642, which may have influenced an undoubtedly traumatized Margaret Lucas to become maid of honour to Queen Henrietta Maria in 1643. When the court was forced into exile in France in 1644, Lucas followed. It was in Paris that she was to meet William Cavendish, then Marquis of Newcastle. Not long afterward she became his second wife. Thus married into an aristocratic family, she became a woman of leisure.

Supported by her husband, Cavendish devoted herself to natural philosophy. As she was attracted to atomism, her Poems, and Fancies (1653) 
and Philosophicall Fancies (1653) were "among the very first texts to import Gassendi's revival of Epicurean atomism from France into England." ${ }^{32}$ But, unlike Descartes or Walter Charleton, she never attempted to discard any of atomism's atheistical connotations. ${ }^{33}$ Instead, she presented matter as the only ordering principle; according to her, sharp, long, round, and square atoms respectively constitute fire, air, water, and earth:

The square flat Atomes, as dull Earth appeare,

The Atomes Round do make the Water cleere.

The Long Streight [sic] Atomes like to Arrowes fly,

Mount next the points, and make the Aiery Skie;

The Sharpest Atomes do into Fire turne,

Which by their peircing quality they burne..$^{34}$

Even in her earliest work we already discern her scepticism about sense perception and the attainment of true knowledge. The physical body with its sensory functions is often unable to detect things, such as atoms:

For Sense is grosse, not every thing can Shape.

So in this World another World may bee,

That we do neither touch, tast, smell, heare, see. (Poems, 43) $)^{35}$

32. Battigelli, p. 50.

33. Battigelli, p. 50.

34. Margaret Cavendish, Poems, and Fancies written by the Right Honourable, the Lady Margaret Newcastle (London: Printed by T. R. for J. Martin, and J. Allestrye at the Bell in Saint Pauls Church Yard, 1653), p. 6. Subsequent references to this text will appear as "Poems" with a page number in parentheses in the main text.

35. The senses, but also the mind can delude: "Some Ages in Opinion all agree, / The next doth strive to make them false to be. / But what is, doth please so well the Sense, / That Reasons old are thought to be Non-sense. / But all Opinions are by Fancy fed, / And Truth under Opinions lieth dead" (p. 39). For a more thorough examination of Cavendish's scepticism as expressed in her atomism, see Battigelli, pp. 39-61. At this stage, however, atomism provided her first and foremost with a metaphor that, according to Battigelli, "proved useful in explaining political and psychological conflict, and she used it to explore her thoughts publicly as she struggled to cope with a world that seemed to be forever at odds with her and her family. [...] The epistemological skepticism she embraced as a result of her inquiry into atomistic systems presented one response to the crisis of authority that catapulted England into civil 
As we shall see, this scepticism was also reflected in her complicated selfrepresentation as an author, wife, and woman. By the time she published her Philosophical and Physical Opinions in 1655, she had abandoned atomism as a theory that explained matter. ${ }^{36}$ She turned to an organic materialism with an inherent hierarchy, which she favoured over the democratic implications of atomism's equality in matter. She held that matter and motion are inseparable. She understood matter as one, "yet there seemeth to human sense and reason to be several Degrees in that One kind of Matter": ${ }^{37}$ rational matter, self-moving and self-knowing, was the superior kind. It governs sensitive matter, which is responsible for sense perception, and inanimate matter, the lowest kind.

Cavendish supported the idea that nothing, not even the soul, is immaterial. This justifies her assertion that empirical observation cannot lead to complete knowledge, as observation cannot unveil everything in such a varied material nature. Matter cannot know all other matter, as she also explains in Grounds of Natural Philosophy (1668): "Although the Exterior Parts of one Creature, can but perceive the Exterior Parts of another Creature; yet, the Rational can make Conceptions of the Interior Parts, but not Perception: for, neither the Sense, nor Reason, can perceive what is not present, but by rote." 38 This vitalist view informs her basic idea that a physical entity, a body, a person, cannot absolutely consolidate knowledge, even though she emphasizes that observation is important. It is as if she is torn between a fascination with empirical observation and a rejection of what she perceived to be the New Science's arrogance in claiming that nature can truly be known. In her Observations Upon Experimental Philosophy $\left(1666,2^{\text {nd }}\right.$ ed. 1668) she states that "[i]n my opinion, the surest way both in Diseases and Applications of Remedies, is, to observe the corporeal, figurative motions of both, which are best and surest perceived by the Rational perception, because the Sensitive is more apt to be deluded." ${ }^{39}$

war; by warning her readers of the unreliability of the senses, she must have hoped to help ward off the kind of conflict that led to war" (p. 60).

36. Battigelli states that "while she rejected atomism as a theory of matter, she retained it as a metaphor for society and for the mind" (p. 60).

37. Cavendish, Philosophical and Physical Opinions. Written By the Thrice Noble, Illustrious, and Excellent Princess, the Lady Marchioness of Newcastle (London: Printed by William Wilson, 1663), p. 2.

38. Margaret Cavendish, Grounds of Natural Philosophy (London: A. Maxwell, 1668), p. 23.

39. Margaret Cavendish, Observations Upon Experimental Philosophy: To which is added, the Description of a New Blazing World, $2^{\text {nd }}$ ed. (London: A. Maxwell, 1668), p. 339. All subsequent quotations are taken 
Observations can be made, but the delusion of the senses complicates matters; observations depend on a body in which rational and sensitive matter are intermixed, and which is thus far from flawless.

Lisa T. Sarasohn has indicated that Cavendish's scepticism and whimsical imagination were the result of her sex and upbringing (and lack of education). ${ }^{40}$ Cavendish indeed used this as an excuse. ${ }^{41}$ However, it is important to bear in mind, first, that her scepticism and probabilism (as identified by Stephen Clucas) ${ }^{42}$ could be regarded as a conscious strategy of opposition rather than a consequence of and defensive cover for her ignorance, ${ }^{43}$ and second, that Cavendish married into a family that sought out intellectual companionship. Elspeth Graham points to the fact, for instance, that Cavendish's stepdaughters wrote plays for private performance and that "closet drama itself, once viewed as limited, amateurish drama confined to the realm of the family, in fact had a much wider cultural influence and significance in the mid-seventeenth century than was once thought." ${ }^{4}$ Moreover, the "Newcastle circle" that formed around William and his brother Charles Cavendish included Kenelm Digby, and, when

from this edition. Page numbers will follow in parentheses in the main text.

40. Lisa T. Sarasohn, "A Science Turned Upside Down: Feminism and the Natural Philosophy of Margaret Cavendish," Huntington Library Quarterly 47, no. 4 (1984), p. 292. Sarasohn suggests that "while skepticism led other philosophers to develop new methodologies based on experimentation and the careful use of reason, the duchess used skepticism to justify wild flights of imagination [...] Cavendish had no choice but to advocate full-scale skepticism; the path to conventional knowledge was closed to her" (p. 292).

41. I will elaborate on Cavendish's stance on woman's intellectual capacities below, in comparison with Trye.

42. Stephen Clucas, "Variation, Irregularity and Probabilism: Margaret Cavendish and Natural Philosophy as Rhetoric," in A Princely Brave Woman: Essays on Margaret Cavendish, Duchess of Newcastle, ed. Stephen Clucas (Aldershot: Ashgate, 2003), pp. 199-209.

43. I refer, once more, to Battigelli's examination of Cavendish's sceptical atomism: Battigelli, p. 39-61. See also Hilda Smith, "Margaret Cavendish and the Microscope as Play," in Men, Women, and the Birthing of Modern Science, ed. Judith P. Zinsser (DeKalb: Northern Illinois University Press, 2005), pp. $34-47$.

44. Elspeth Graham, "Intersubjectivity, Intertextuality, and Form in the Self-Writings of Margaret Cavendish," in Genre and Women's Life Writing in Early Modern England, ed. Michelle M. Dowd and Julie A. Eckerle (Aldershot: Ashgate, 2007), p. 136. See also Marion Wynne-Davies, “How Great is Thy Change': Familial Discourses in the Cavendish Family," in A Princely Brave Woman, p. 48: "family bonds emerge as a powerful way of uniting female literary productivity." 
in exile, Thomas Hobbes, Pierre Gassendi, and René Descartes. Margaret became acquainted with these men and their works, although her shyness might not have allowed her to converse with them as much as she probably wanted to. ${ }^{45}$ Cavendish's brother, John Lucas, was also one of the original Fellows of the Royal Society. ${ }^{46}$ Even though Cavendish was always quick to defend her natural philosophical work as entirely her own, her writing increasingly shows external influences and constitutes reactions against other theories. ${ }^{47}$ Cavendish admits in later works such as the Observations that her former contemplations were not so well informed since she had not read much at the time. She goes from claiming that all originated out of her own wit, ${ }^{48}$ to claiming that she is now better equipped to discuss philosophical matters because she has read other works:

Courteous Reader, I Do ingenuously confess, that both for want of Learning and reading Philosophical Authors, I have not expressed my self

45. William Cavendish, in the "Epistle to justify the Lady Newcastle," introducing Philosophical and Physical Opinions, maintains that his wife did not converse with the scholars that visited their household, but that he, his brother Charles, and her own brother John Lucas introduced her to everything there is to know in the world.

46. Londa Schiebinger, The Mind Has No Sex? Women in the Origins of Modern Science (1989, repr.; Cambridge, MA: Harvard University Press, 1991), pp. 48-49.

47. Cavendish is critical of Galenic medicine as well as Paracelsianism in her Observations (p. 334), and claims that "if Paracelsus was as frequently practised as Galen, it would be as bad as the Plague" (p. 336). Sarah Hutton discusses Cavendish's reaction to Hobbes in "In Dialogue with Thomas Hobbes: Margaret Cavendish's Natural Philosophy," Women's Writing 4, no. 3 (1997), pp. 421-32.

48. Ingo Berensmeyer points to the frontispiece to The Philosophical and Physical Opinions (1655), where the portrait of Cavendish in an empty shrine is inscribed as follows: "Her library on which she look's / It is her Head her Thoughts her Books." Although she corresponded with Constantijn Huygens, Berensmeyer explains that this visual reinforcement of her independence from others also illustrates the lack of formal response to her work. See Ingo Berensmeyer, "Simulierter Gelehrtenstreit: Margaret Cavendish und die Selbstinszenierung Weiblicher Autorität im 17. Jahrhundert," Zeitsprünge: Forschungen zur Frühen Neuzeit 15, no. 2/3 (2011), p. 330. For her correspondence with Huygens, see Nadine Akkerman and Marguérite Corporaal, "Mad Science beyond Flattery: The Correspondence of Margaret Cavendish and Constantijn Huygens," Early Modern Literary Studies, special issue 14 (2004), pp. 1-21. For Cavendish's correspondence with Christiaan Huygens about microscopy, see Smith, "Margaret Cavendish and the Microscope as Play," pp. 40-42. Another frontispiece, to Natures Pictures (1656), shows her in the comfort of her home, in the company of her husband and several other men and women. Natures Pictures drawn by Fancies Pencil to the Life (London: Printed for J. Martin, and J. Allestrye, at the Bell in Saint Paul's Church-yard, 1656). 
in my Philosophical Works, especially in my Philosophical and Physical Opinions, so clearly and plainly as I might have done, had I had the assistance of Art, and the practice of reading other Authors. (Observations, “To the Reader," b4r)

Her critique of observational science remains more or less the same, but the background and form in which this critique comes can be said to be influenced by a more interactive scientific mode of action and reaction, i.e., of getting acquainted with others' opinions on the matter by actually reading their accounts, assimilating their views, and eventually reacting upon or against them. To state that, in opposition to Trye, Cavendish chose to discard mechanist philosophy or empiricism only because she did not have the possibility to gain more indepth knowledge is too simple. Cavendish explicitly mentions that her husband owned "as many sorts of Optick Glasses as any one else" (Observations, a3r), and in a discussion of a chrysalis the reader may notice how eager she must have been to learn things through first-hand experience and observation. Cavendish's distancing from the New Science can also be explained, as Eve Keller remarks, by the fact that experimental philosophy was not generally acknowledged as producing objectively verifiable results. ${ }^{49}$ We only have to think of Thomas Shadwell's The Virtuoso (1676) - which satirized the Royal Society and was dedicated to William Cavendish-to be reminded of the fact that this scepticism even found its way onto the stage..$^{50}$

Cavendish felt compelled to defend her theory against allegations of a lack of stable foundations. Although she apologizes for her lack of learning, she asserts that there is no "firmer foundation, than that 'material nature': nor [...] a better method, than that of 'sense' and 'reason'” (Observations, 21). As already mentioned, her refusal to represent a more thorough-going, consistent system of thought and knowledge can be considered an intentional epistemological critique of the Royal Society and empirical science as a whole, based on probabilism and utilitarianism, which means that her philosophy does have rules, albeit Cavendish's own rules. ${ }^{51}$ Her sceptical critique affects her view of nature, the body, and thus also the role of the witness, whether that witness is physically

49. Eve Keller, "Producing Petty Gods," p. 450.

50. Thomas Shadwell was on good terms with the Cavendishes. The Sullen Lovers (1668), Epsom Wells (1673), and The Libertine (1676) were also dedicated to William Cavendish.

51. See Keller, “Producing Petty Gods," pp. 447-71. 
real or comes in the textual form of the author (see below). Cavendish's scepti$\mathrm{cism}^{52}$ about the empirical epistemology translates into a probabilistic presentation of her own methodology:

However I do not applaud my self so much, as to think that my Works can be without errors, for Nature is not a Deity, but her parts are often irregular: and how is it possible that one particular Creature can know all the obscure and hidden infinite varieties of Nature? if [sic] the Truth of Nature were so easily known, we had no need to take so much pains in searching after it; but Nature being Material, and consequently divisible, her parts have but divided Knowledges, and none can claim an Universal infinite Knowledg. Nevertheless, although I may err in my Arguments, or for want of Artificial Terms; yet I believe the Ground of my Opinion is True, because it is Sense and Reason. (Observations, "To the Reader," c2r-c2v)

But even this probabilism is problematic. As Stephen Clucas has noticed, it displays some similarities with some of the Fellows' work. As Robert Boyle "attempts to authorise inquiry, experiment and investigation, rather than dogma, theory and over-elaborate argument," ${ }^{53}$ his professed artlessness and intention to propose probabilities rather than "truth" sounds familiarly like Cavendish. Clucas continues, however, that "in her case the 'ingenious and free' discourse of wit and fancy, or rational contemplation notionally unguided by reliance on empirical data, is promoted rather than experimental investigation." ${ }^{54}$ Clucas also recognizes that

what sets Cavendish's probabilism and limited scepticism apart from that of other mid-century philosophers, $[\ldots]$ is its derivation from her physical theories. Whereas Charleton emphasised man's fallen nature, and Boyle's essayistic probabilism developed out of his commitment to open-ended experimental investigation, Cavendish's beliefs regarding the

52. It is important to note, however, that she did not adhere to a radical scepticism that claims that nothing can ever be known; see Clucas, p. 203.

53. Clucas, p. 201.

54. Clucas, p. 201. 
limits of knowledge relate directly to her conception of nature as infinitely various. $^{55}$

Her scepticism and insistence on the "infinitely various" character of nature applies to the physical body and thus also Cavendish's view of the witness and her self-representation as a witness and author. For the reader it is often difficult to pinpoint Cavendish's particular stance.

By the time she published Observations upon Experimental Philosophy, to which is added the Description of a New Blazing World (1666; $2^{\text {nd }}$ ed. 1668), she specifically aimed her arrows at experimentalism and its instruments. In The Blazing World, she appears to make a game of the witnessing process. ${ }^{56}$ Here, in keeping with her claims in her Observations, the notion of experimental empiricism and the function of witnesses in experiment seem especially to be questioned. When the Empress of the Blazing World grows angry with the Bear-men, who cannot present her with any true and practical knowledge with their telescopes or microscopes, she commands them to break the instruments. Indeed,

if their glasses were true informers, they would rectify their [the Bearmen's] irregular sense and reason; but, said she, nature has made your sense and reason more regular than art has your glasses, for they are mere deluders, and will never lead you to the knowledge of truth. ${ }^{57}$

Here, she emphasizes unmediated observation. Moreover, Sarah Hutton has also illustrated the intentional irony with which Cavendish lets the Empress consult immaterial spirits (which are purely fictional, according to Cavendish's materialism) who then tell her that the source of motion is matter, and not spirit. ${ }^{58}$ The Empress then has the soul of the Duchess of Newcastle, a fictional

55. Clucas, p. 205.

56. Blazing World is Observations' fictional counterpart. Although these works have often been analyzed separately, they were published as a whole, as the title indicates, and the ideas in both works confirm each other. See Berensmeyer, pp. 325-41.

57. Margaret Cavendish, The Blazing World and Other Writings, ed. Kate Lilley (London: Penguin, 2004), pp. 141-42. All subsequent quotations from the Blazing World are taken from this edition; page numbers will follow in parentheses in the main text.

58. Sarah Hutton, "Margaret Cavendish and Henry More," in A Princely Brave Woman, p. 194. 
Margaret Cavendish, summoned to her court in order to serve as her scribe. Cavendish describes how, after having developed a friendship-platonic love is mentioned-the two female souls of the Empress and the scribe "travelled together as lightly as two thoughts into the Duchess her native world; and which is remarkable, in a moment viewed all the parts of it" (190). They observe the Duchess's husband, William Cavendish, for a while, and eventually end up in his body, where the three souls almost form a ménage à trois. The Duchess's soul asserts her husband's many qualities and recounts how Fortune has not treated him kindly, whereupon the Empress agrees to settle the dispute between the Duke and Fortune. Before the judge, Truth, the Duchess pleads the case "in the behalf of my noble lord and husband, since he is not here himself" before an "immaterial assembly" (197). The reader is presented with all sorts of witnesses throughout the story: bear-men, fly-men, immaterial spirits, souls .... And when the reader is then led to believe that the soul of the Duchess is the only reliable witness, this soul oddly enough seems to be described in terms that hint at immateriality: the narrator, perhaps ironically, assures the reader that "souls cannot travel without vehicles" (193). This is especially confusing since the reader is forced to identify the Duchess with the author, who rejected the idea of immateriality. Witnesses seem unable to provide certainty, and it is as if the soul of the Duchess can only be pinpointed as a spokesperson for her husband.

In real life, Cavendish even "acted out" her probabilistic and epistemological critique in 1667, when she visited the Royal Society and was the talk of the town. The story of how she attended the presentation of some experiments has attained an almost iconic value for Cavendish scholars: after having drawn a crowd in the streets of London, Cavendish, almost speechless at the sight of the workings of Boyle's air pump, was compared to a madwoman who had nothing of interest to say. ${ }^{59}$ Why did she ensure, by her behaviour, that all attention should be fixed on her, while she was unable to make any critical remarks? Was she making an ironic statement by seemingly giving vent to her feelings of wonder and amazement, whereas before she was known to criticize the empirical, experimental program? Was it stage fright, as she was placed in a strange environment, seeing bizarre experiments, aware of the fact that she was the first 
woman to visit the Royal Society? Or did she fear that "publicly" questioning the value of the experiments was a bridge too far for a woman? Or perhaps it was her innate shyness that prevented her from making any remarks.

It might be argued that her visit did not lend her the credibility she sought. Her uncritical reaction at the sight of the experiments performed seems all the more strange since her Observations and The Blazing World are very clearly meant to criticize the foundations of empirical science as championed by the Royal Society. In the same way that experiments at the Royal Society needed to be conducted in the presence of witnesses to gain credibility, Cavendish's visit to that very institution might actually be considered as a witnessing performance as well, resembling the fictional account of The Blazing World, where the role of the observer is questioned. Her puzzling "live" performance showed, first, that the observation of an experiment is little more than merriment before an enthralled audience. Moreover, she would not allow the attending Fellows to pierce her façade. Objective observation has its limits. ${ }^{60}$ Second, this physical performance of hers also served a more socio-political purpose. Similar to the way in which the Duchess's soul in The Blazing World calls attention to her husband's predicament, Cavendish's performance put herself and her husband at the centre of attention again in an attempt to affirm that she (and consequently also her husband) still deserved to be heard. Cavendish was aware of the fact that everything she did, and thus also the presentation of her natural philosophy, affected her husband as well. Here, the empirical witness becomes a spokesperson for her husband. The one thing that is never questioned, and which is always easy to observe, is the virtue of William Cavendish.

By now it is clear that her reinterpretation of the concept of the validating witness in experimental empiricism allows one to consider the fact that she wrote not only because the conditions were right for her but also because the conditions were wrong for her husband. Just like Trye, she finds stability in the defence of a male member of the family who has been wronged. Both Thomas O'Dowde and William Cavendish were royalists who were not particularly rewarded for their loyalty. Cavendish's husband's situation as a royalist teetering on the brink of ruin was a driving force that allowed her, as "wife of," to find a justification for her urge to write and to combine shyness and boldness in 60. Keller similarly argues that Cavendish's "proliferation of selves and worlds" in the Blazing World is an extended epistemological critique of empiricism, since the New Science is based in the "assumption of a discrete self and a stable object." Keller, "Producing Petty Gods," p. 463. 
her authorial assertion, a stance to which her dedications and prefaces testify. The background of social, cultural, and intellectual conditions at the time, as described by Hero Chalmers, inevitably impels one to examine her image as an (aristocratic) wife, an image which plays an important part in her authorial self-fashioning. Chalmers demonstrates that her sometimes aggressive authorial stance should be regarded as a "form of legitimate self-display," "enabled by factors associated with her position as a displaced royalist during the 1650s." ${ }^{\prime 61}$ Moreover, Chalmers claims that she did not transgress feminine modesty. It was Cavendish's duty to "participate in establishing her husband's social status through self-display," and to make sure that the exiled royalists were not forgotten. However, after the Restoration "her more aggressive style of feminine self-publicization ceases to be as immediately excusable as a gesture or emblem of suppressed royalist resistance." ${ }^{62}$ This representation was then still a question of wifely duty and class-hierarchy, but it was no longer a matter of royalist resistance. Instead, Cavendish's authorial self-assertion relies more and more on her husband's approval, although she still considers herself the public representative of her husband, who was once more disregarded by the court.

An example of the extent to which she connected her authorial representation to her husband is to be found in the Observations, where a conversation materializes between husband and wife by means of a dedicatory poem by William Cavendish on the one hand and Margaret Cavendish's response to his praise on the other. William Cavendish admires the book in "To Her Grace The Duchess of Newcastle, on her Observations upon Experimental Philosophy": "For this will give you an eternal fame, / and last to all posterity your name: / You conquer Death, in a perpetual Life; / And make me famous too in such a Wife" (Observations, a2r). Indeed, her husband was very much aware of how her writing affected his own image. The duchess's answer to her husband's praise, "To His Grace The Duke of Newcastle," emphasizes how her husband's view resembles her opinion that the artificial instruments of the New Science, such as microscopes and telescopes, are not useful in the quest for truth (Observations, a3r). It ends with the assertion that all she desires is "your Graces Approbation."

61. Hero Chalmers, "Dismantling the Myth of 'Mad Madge': The Cultural Context of Margaret Cavendish's Authorial Self-Presentation," Women's Writing 4, no. 3 (2010), p. 323

62. Chalmers, p. 333. 
Again, this public marital conversation gives the impression that her husband's socio-political position was more of a driving force than generally considered.

This comes as no surprise, as the most acceptable physical position in which women could place their image as writer and witness was a domestic one, either as a wife, as in Cavendish's case, or as a daughter, as in Trye's case. Since women were generally associated with domesticity and family, any female scientific writer, before she could begin to claim any authority in the field of science or as an author tout court, had to deal with an assigned background of traditional female roles. ${ }^{63}$ This applies even to Cavendish, who had a troubled and perhaps contradictory relationship not only with experimental science, but also with domestic life. I argue that her ambiguous position in the empirical debate and her equally ambiguous authorial self-representation are not only reflections of her critique on the empirical epistemology, but also due to her association of household experience with empirical experience and experiment, and her unwillingness to assume a steady domestic image. A comparison with Trye's stance on domesticity and women's intellectual capacities shows just how difficult it was for Cavendish to assume a stable domestic position.

\section{Comparing Trye's and Cavendish's defences}

Trye's rhetorical power manifests itself clearly when she wields her irony like a sword, especially when she considers female authorship. Despite her ironic, self-deprecating remarks that she will not expand on how "my feminine hand came to write" (3) because she wants to "avoid prolixity, which is a crime we Women are commonly guilty of" (3), she asserts her abilities as female practitioner and author for the greater good-and also for her own good, for she still has to make a living as a medical practitioner. She strongly affirms that "I must take liberty to tell Mr. Stubbe, That I am satisfied there is Ability enough in my Sex, both to discourse his envy, and equal the Arguments of his Pen in those things that are proper for a Woman to engage" (2). Although careful not to break too many social norms by touching upon subjects that are deemed unfit

63. It is necessary to stress that the early modern household was not the private realm that would begin to emerge in the eighteenth century. Medical care for family and friends started in the kitchen, with food and medicines, and even the birthing-room was a place for female family and friends. For medicine and the household, see Wear, pp. 49-65; for birthing-rooms and midwifery, see Hilary Marland, ed., The Art of Midwifery: Early Modern Midwives in Europe (1993; Abingdon: Routledge, 2005). 
for a woman, she intends to show that she can strike back and that women are capable of medical practice and debate. She will employ her pen with feminine propriety to prove Stubbe wrong.

In her dedicatory letter she styles herself as "one of the Feminine Degree," who "in a Medicinal Contest, hath now encountered a Rhetorical and Physical Hector, an expression I confess too generous for one that deserves so little" (Epistle Dedicatory, A2v.). Presenting herself as a very confident woman, she puts herself on a par with Achilles, which hardly indicates a fear of hubris. Trye's irony undermines the patronizing view of women writers when she states that, because Plutarch and Aesop are now available in translation, "this Age [is] pretty kind to us Females in such assistance," or that Stubbe "will be so kind as to excuse me for the vacancy of those Masculine Capacities he himself glories in" (5). This is her pre-emptive strike against potential negative comments that would dismiss her work on the basis of her sex. To my knowledge, there was no direct response by Stubbe to this attack-a silence that denies Trye the status of an opponent worthy of reply, perhaps; Cavendish's work was met with the same silence, at least in print, which might indicate an unwillingness of men to stoop to argue with a woman or to display any kind of "ungentlemanly" behaviour. Furthermore, Trye touches a sore spot when she says that "such fine things, as are prettily term'd Philosophical in him, will scarce be thought rational in me" (5). She knows that she has to work twice as hard to prove herself, compared to any man, and she is not afraid to give her opinion on that matter. ${ }^{64}$ Another consequence of being a woman is that Trye, just like Cavendish, is bound to deal with a domestic or familial image of women. She chooses to take the position of a daughter in a small "family business" of chemical medical practitioners. Rather than being a limiting factor, this position allows her to honestly defend women's capabilities as writers and medical practitioners, and, as I have already discussed, places her in a tradition of chemical medicine and its practice.

In any case, Trye does not use gender as an excuse for potentially inferior writing, unlike Cavendish. Indeed, the latter takes a very different stance on female propriety, sometimes lamenting the plight of women but also claiming disparagingly that women who like to experiment in the kitchen are unfit for

64. Trye was writing at a time when the competence of midwives was also being questioned. See Jane Sharp, The Midwives Book. Or the Whole Art of Midwifry Discovered (London: Printed for Simon Miller, at the Star at the West End of St. Pauls, 1671). 
true natural philosophy (Observations, 103). ${ }^{65}$ In spite of her rationalist epistemology, Margaret Cavendish was well aware of the fact that social conventions and even the human body, both real and socially constructed, affected who was perceived as authoritative enough for his or her statements to become accepted as public knowledge. Cavendish played with these assumptions:

I do undertake to write beyond my experience; for which, 'tis probable, Artists will condemn me; but if I err, I ask their pardon, and pray them to consider the Nature of our Sex, which makes us, for the most part, obstinate and wilful in our Opinions, and most commonly impertinently foolish. (Observations, 268)

Insistence on bodily witnessing provided another opportunity for debates about the nature of the female body, and whether or not this nature could accommodate any intellectual capabilities. Since the witness finds herself at the centre of a web of interrelations between observed phenomena, discourse, and the social, the real (bodily) differences between witnesses can easily become socially inscribed. For instance, because the female body was still believed, according to ancient Galenic, humoral theory, to be colder and wetter than the more perfect (because hotter and drier) male body, ${ }^{66}$ women's mental capacities were seen as limited, too; therefore, females were considered less authoritative in intellectual matters. They were also easily identified with an "irrational" body part, the womb, which was believed to cause "fits of the mother," or hysteria. ${ }^{67}$ As a consequence of this preconception, for women to be accepted as textual or physical witnesses was problematic even in the New Science. Cavendish

65. Deborah Boyle claims that Cavendish's "rejection of empiricism does not mean that [she] embraces a 'feminine mode of knowing." See Deborah Boyle, "Margaret Cavendish's Nonfeminist Natural Philosophy," Configurations 12, no. 2 (2004), p. 211.

66. See Mary Lindemann, Medicine and Society in Early Modern Europe, $2^{\text {nd }}$ ed. (2010; Cambridge: Cambridge University Press, 2012), pp. 17-18. For more information on the perception of female inferiority in terms of anatomy, intellect, and medical practice, see Leigh Whaley, Women and the Practice of Medical Care in Early Modern Europe, 1400-1800 (Basingstoke: Palgrave Macmillan, 2011), pp. $48-67$.

67. For more information on "the wandering womb," see Eve Keller, Generating Bodies and Gendered Selves: The Rhetoric of Reproduction in Early Modern England (Seattle: University of Washington Press, 2007), pp. 94-97; Kaara L. Peterson, Popular Medicine, Hysterical Disease, and Social Controversy in Shakespeare's England (Aldershot: Ashgate, 2010), pp. 26-27. 
concedes that women have "softer" brains, but believes it is unjust that they are denied proper education:

But that I am not versed in Learning, no body, I hope will blame me for it, since it is sufficiently known, that our Sex being not suffer'd to be instructed in Schools and Universities, cannot be bred up to it. I will not say, but many of our Sex may have as much wit, and be capable of Learning as well as Men; but since they want Instructions, it is not possible they should attain to it: for Learning is Artificial, but Wit is Natural. (Observations, “To the Reader," b4v)

In physical terms women did not attain enough authority among peers to be taken seriously when disseminating their accounts and thoughts in print among a wider audience. Still, Cavendish tried to do away with the prejudice that knowledge belonged only to men.

And yet, her opinions on women's household duties are at times quite belittling. Ironically, certain "middle class" women were more favourably disposed towards an empirical trend in science as they were makers of medicines, experimenters in "kitchen physick," and providers of medical care for family, friends, and neighbours. ${ }^{68}$ This may explain Cavendish's derogatory stance on women's household duties as banal; in her opinion, the sheer physicality of them can never lead to knowledge, and the testing of new things in the kitchen is merely a way of killing time. In that sense, she says, household work resembles the experiments of the Royal Society, and women would make good experimenters:

To what purpose should a man beat his brains, and weary his body with labours about that wherein he shall lose more Time, than gain Knowledg? But if any one would take delight in such things, my opinion is, That our Female-sex would be the fittest for it; for they most commonly take pleasure in making of Sweet-meats, Possets, several sorts of Pyes, Puddings, and the like; not so much for their own eating, as to employ their idle time; and it may be, they would prove good Experimental Philosophers, and 
inform the world how to make Artificial Snow, by their Creams, or Possets beaten into froth: and Ice, by their clear, candied, or crusted Quiddities, or Conserves of Fruits [...] But the Men should study the Causes of those Experiments: and by this Society, the Commonwealth would find a great benefit. For the Woman was given to Man, not onely to delight, but to help and assist him; and I am confident, Women would labour as much with Fire and Furnace, as Men; for they'l make good Cordials and Spirits; but whether they would find out the Philosophers-Stone, I doubt; for our Sex is more apt to wast, than to make Gold: However, I would have them try, especially those that have Means to spend; for, who knows but Women might be more happy in finding it out, than Men; and then would Men have reason to employ their time in more profitable Studies, than in useless Experiments. (Observations, 103-04)

This shows how far housewifery experience was considered similar to experience in empirical science. Since Cavendish rejected empirical epistemology, she also found it hard to take on the role of housewife. ${ }^{69}$ However, in this very negative description of women and women's work, one also finds a telling passage that strengthens the argument that Cavendish's witness also partly functions as a spokesperson for her husband: "For the Woman was given to Man, not onely to delight, but to help and assist him." Cavendish evidently wants to portray herself as a virtuous wife. Unfortunately for Cavendish, this was most often considered equivalent to being a good housewife. The equation "good wife $=$ good housewife $=$ experience $=$ empirical methodology $=$ empirical epis temology" is troublesome for her, as she had a problematic relationship with two parts of that equation, namely housewifery and empirical epistemology. To some extent, Cavendish knew more about housewifery and estate management than is often thought: Hilda Smith refers to the fact that she was accused of "giving too close scrutiny to the Welbeck estate books" and provides an account of Cavendish's ability to take resolute action. ${ }^{70}$ Cavendish herself claimed in her

69. Lara Dodds also examines Cavendish's relationship with housewifery and its connection with empirical experience and experiment. See Lara Dodds, "Margaret Cavendish's Domestic Experiment," in Genre and Women's Life Writing in Early Modern England, ed. Michelle M. Dowd and Julie A. Eckerle (Aldershot: Ashgate, 2007), pp. 151-68.

70. Hilda Smith, "Margaret Cavendish and the False Universal," in Virtue, Liberty and Toleration: Political Ideas of European Women, ed. Jacqueline Broad and Karen Green (Dordrecht: Springer, 2007), 
Philosophical and Physical Opinions that the little she knew about anatomy came from her having seen animals slaughtered and butchered, ${ }^{71}$ and her Poems, and Fancies is filled with housewifery analogies and metaphors. But the fact that she mentions, for instance, "oil of swallows" (Poems, 73) - a well-known ointment for bruises-or hopes that her verses will be "strew'd with some Sugar of Praises, and Bake'd in the Oven of Applause" (Poems, 122), cannot be considered evidence for her practical household skills.

Having spent a large part of her married life in exile on the continent must also have complicated her position. With the estates at Welbeck and Bolsover sequestered or simply out of reach due to inimical political circumstances before the Restoration, one can imagine that Cavendish felt that she had no household of her own to govern. ${ }^{72}$ So she decided to be a good wife in a different way, and translated good housewifery in a sort of writing that she depicts as the next best thing. Although Poems, and Fancies is dedicated not to her husband but to her brother-in-law, the homely imagery serves to support her intellectual work, as she proclaims

True it is, Spinning with the Fingers is more proper to our Sexe, then studying or writing Poetry, which is the Spinning with the braine: but I having no skill in the Art of the first [...] made me delight in the latter; since all braines work naturally, and incessantly, in some kinde or other; which made me endeavour to Spin a Garment of Memory, to lapp up my Name, that it might grow to after Ages: [...] But certainely your [Charles Cavendish's] Bounty hath been the Distaffe, from whence Fate hath Spun the thread of this part of my Life, which Life I wish may be drawne forth in your Service. ${ }^{73}$

She tends towards domestic imagery in this exaltation of another Cavendish, but chooses the image of the intellectual wife over the industrious housewife:

pp. 102-03.

71. Margaret Cavendish, "The Preface to the Sixth Part," in Philosophical and Physical Opinions, Kk1v-Kk2r.

72. See Poems, and Fancies, A7r: "I have no Children to imploy my Care, and Attendance on; and my Lord's estate being taken away, had nothing for Huswifery, or thrifty Industry to imploy my selfe in." See also Dodds, p. 151.

73. Cavendish, "The Epistle Dedicatory," in Poems, and Fancies, A2r-A2v. 
"I cannot for my Life be so good a Huswife, as to quit Writing [...] the truth is I have somewhat Err'd from good Huswifry, to write Nature's Philosophy."74 Of course, Cavendish tends to play with cause and effect, and I do not claim that she merely writes to represent her husband or to compensate for a lack of household skills. The family she married into and the household work that it entailed (or was supposed to entail) are used in a defensive rhetorical strategy. At times she claims to have some experience as a housewife, but not enough to be able to represent herself as familiar with experience and experiment. In this light, it is important to bear in mind that Cavendish's social position informed her rather abstract, theoretical natural philosophy. Part of the conflicting interpretations of the witness and the views of science that Cavendish and Trye held can be traced back to their belonging to what Hilary Rose identifies as different groups of women in science. Aristocratic women like Cavendish were "doing abstract disembodied science [...] and their lives like those of their male counterparts were nearer to the library than women of the middling classes.".75 Trye, on the other hand, belonged to the "middling classes with their closer relationship to household production, [who] tended to be stronger on empirical knowledge: the doctors, midwives and the food technologists." ${ }^{16}$ This is only partly true, however, as many aristocratic women were not strangers to "kitchen physick." Moreover, Cavendish's critique of microscopes, for instance, is also driven by utilitarianism: "if Microscopes do truly represent the exterior parts and superficies of some minute Creatures, what advantageth it our knowledg?" (Observations, b2v). ${ }^{77}$ According to her, the inspection of a bee would not lead to more honey.

Despite Trye and Cavendish's different interpretations of their roles as female witnesses, the fact remains that they both felt the need to defend their positions as female writers starting from a more familiar domestic setting, also representing a wronged father or husband-even if they went in opposite

74. Cavendish, "To his Excellencie the Lord Marquis of Newcastle," in Philosophical and Physical Opinions, (1663); also quoted in Schiebinger, p. 58.

75. Hilary Rose, foreword to Women, Science and Medicine, p. xiv.

76. Rose, p. xiv. The third group, according to Rose, was "closely connected to men involved in the new public production system of science (Howard, Boyle, Evelyn, and Flamsteed), [and] were centrally part of the new theory-driven experimentalism."

77. Smith addresses Cavendish's utilitarianism as a source of her scepticism in "Margaret Cavendish and the Microscope as Play." 
directions from there on. Both also defend their sex's intellectual capacities-if only to some extent on the part of Cavendish. And there is more that they have in common. Strongly wedded to their defence of women's intellectual capabilities is their emphasis on simple language and the use of the vernacular. ${ }^{78}$ Despite her own rhetorical prowess, Trye rails against a scholastic verbosity, and remarks ironically that she is grateful that translations have come to the assistance of poorly educated women. Similarly, Cavendish states that

those that fill their Writings with hard words, put the horses behind the Coach, and instead of making hard things easie, make easie things hard, which especially in our English Writers is a great fault; [...] although I do understand some of their hard Expressions now, yet I shun them as much in my Writings as is possible for me to do. (Observations, "To the Reader," c1r)

Trye and Cavendish were not the only authors to call for plain language. It fit into a larger tendency to express ideas in a "plain objective language," reflecting an increasing utilitarian mindset in a culture that also saw a rise in how-to-manuals. ${ }^{79}$

Another element that Trye and Cavendish have in common is a strong language of opposition, which in Trye's case even takes on the form of an ad hominem attack. Despite her disdain for empty rhetoric, at times Trye deploys quite a rhetorical power herself, which she uses, for instance, to compare Stubbe, or the "little Bell of Warwick" as she likes to call him, to Cicero; ${ }^{80}$ according to her, he has as good an opinion of himself as Cicero had, although Cicero surpassed Stubbe in wit (6). Trye's vindication of her father is one thing that fed this rhetorical rage. However, in Trye as well as in Cavendish, this oppositional

78. Green explains that "Women's near universal exclusion from grammar schools, and their total exclusion from the universities meant that they had no formal route to obtain an identical Latinate education as boys" (p. 142). Green also states that "The end of the thirteenth century represents the approximate point at which Latin ceased to be a language in which most literate women felt comfortable" (p. 144).

79. See Elizabeth Tebeaux, "The Voices of English Women Technical Writers, 1641-1700: Imprints in the Evolution of Modern English Prose Style," Technical Communication Quarterly 7, no. 2 (2009), pp. $125-52$.

80. For his “Tinkling," see Trye, Medicatrix, pp. 79-81. 
rhetoric is also partly fuelled by concerns about the intellectual position of women, and partly by ideological disagreements. In spite of the rising number of published female authors, both Cavendish and Trye felt compelled to defend their publications. In doing so, their keep still partly depended on men, not because their capacities did not allow them to do otherwise, but simply because the theories and models they included, or against which they reacted, were defended by male individuals. Other men's theories necessarily had to be incorporated into their alternative model as well. It comes as no surprise, then, that at a time when "accepted" and "public" science was dominated by menas opposed to the more domestic, but no less pervasive science and medicine of women-female writers such as Cavendish and Trye had to engage in this scientific rivalry, which at times was characterized by a rhetorical mode that would normally be attributed to men because of its assertive and sometimes openly aggressive tone. ${ }^{81}$ Compared to scientific texts of today, Trye's confrontational language directed at the physician Stubbe-who, to her, represented all the shortcomings of Galenic medicine-seems at odds with the intended purpose of making a clean, objective scientific statement since she did not engage with the fundamental flaws of Galenic medicine itself. However, as I have shown above, especially in medical debate this language of opposition was far from unusual.

\section{Conclusion}

The seventeenth century is often perceived as a century in which experience and experiment formed the basis for an empirical New Science. This is true, but one must not forget that the science that resulted from it could take on different forms, depending on the interpretation of "experience" and "experiment" by different individuals. An individual's perception of his or her body, and thus its function as a "witness" or observer, reflects his or her concepts of empiricism, or of the attainment of knowledge. This brought along complications for

81. However, I need to stress that even within the antagonistic language of Trye, the language of sympathy for chemical medicine and its practitioners is not lost. Cavendish, however, does not appear to be so quick to present an allegiance with a group or individuals and to support its/their ideas. See, for instance, Susan Fitzmaurice's examination of Cavendish's stance against physicians, in Sociable Letters (1664), in which she assumes the position of a disputant/opponent rather than that of a colleague physician: Susan Fitzmaurice, "Margaret Cavendish, the Doctors of Physick and Advice to the Sick," in A Princely Brave Woman, pp. 210-41. 
women who tried to cast themselves in the role of observer, as the general view of the female body was all but positive.

For women like Cavendish and Trye, their writing was not only a matter of translating their view of the witness, or the "body as instrument," ${ }^{\prime 2}$ into an authorial self-representation that was consistent with their methodological and epistemological ideas; it was also a matter of defending the validity of their observations against accusations that females had no authority due to inferior physical and mental qualities. Although Cavendish and Trye may have differed as regards the first matter, they were united in the second.

One could perhaps argue that it was easier for Trye to assume an unequivocal image as witness, writer, and practitioner, as she positioned herself in a framework of medical empiricism that had few qualms about embodied witnessing. For Trye, empiricism was simple: "Nay, if an Angel should appear with that Doctrine [phlebotomy] at this day, he would not be received; for the Eyes of the World are now open, the Sun Shines, and Experientia docet" (112). Moreover, as her view of medical experience was still easier to reconcile with women's realm of kitchen physick, it was also easier for her to adopt a steady and acceptable authoritative image as writer and practitioner. It was not unusual for women to position themselves in a domestic medical community. ${ }^{83}$ Trye does something like this, although her medical community is mostly professional. Since she chose the community of chemical medicine, which prided itself on an anti-Galenic, hands-on experience (even though much of this experience was often still interpreted in an Aristotelian way), she is quite happy to take on the role of empirical witness, her interpretation of which depends on a physical reality implicitly echoed in her representation of the biological connection between father and daughter. And this, in turn, authorizes her writing. Even on the title page it is very clear that she is "O'Dowde's daughter." As the emphasis is on the author as an intellectual successor, Trye thus inscribes herself as part of a medical and intellectual tradition.

Another reason why it comes more naturally to Trye to adhere to a kind of empiricism is her embeddedness in the medical marketplace. Harold J. Cook

82. See Wolfe and Gal, eds., The Body as Object and Instrument of Knowledge.

83. See for instance Elaine Leong, "Making Medicines in the Early Modern Household," Bulletin of the History of Medicine 82, no. 1 (2008), pp. 145-68; Sara Pennell, "Perfecting Practice? Women, Manuscript Recipes and Knowledge in Early Modern England," in Early Modern Women's Manuscript Writing, ed. Victoria E. Burke and Jonathan Gibson (Aldershot: Ashgate 2004), pp. 237-58. 
has explained how early modern commerce and empirical observation rose at the same time out of a shared sense of curiosity about the world. ${ }^{84}$ Since Trye depended on medical practice for her livelihood, she advertises but refuses to make her recipes public. It is an example of the entrepreneurship typical of Helmontians. The need for commercial attention necessarily also places the author at the centre of attention as the source of medicines and compels her to take into account what patients want. She was materially involved and could not afford the same level of detachment as Cavendish because, as a medical practitioner, Trye was financially dependent on the practical medicinal services she offered as well as on the medicines she advertised.

It is a far cry from Cavendish's abstract natural philosophy, which illustrates that there is no one uniform model for the witness as a mediator between literature and science. Unlike Trye, Cavendish was privileged enough to lead a life of leisure, despite the fact that at several stages of her life she had known relative financial hardships, as she recounts in the True Relation of My Birth, Breeding and Life. ${ }^{85}$ She could not (or would not) assume an unambiguous image of housewife, nor defend the embodied empiricism that was often associated with it. Instead, she chose to engage in the natural philosophical debate that had the additional effect of keeping the Cavendish family on the radar.

It must have been difficult for her to find a clearly defined authorial image, as she refused the traditional position of housewife, and natural philosophy was marked by many different voices among which she was trying to find her own. Generally speaking, in an attempt to find a niche in the natural philosophical debates, Cavendish asserts her authorial self with an ambiguous discourse that is fuelled by her disagreement with the New Science, her assigned domestic place as perceived by conventional society, and her view of the body. Cavendish's complicated authorial image is thus partly a conscious probabilistic critique of what she considered to be empiricism's impossible claim to certainty, but also partly due to an inability to take a stance as to what image to adopt: that of a housewife or not; that of an empirical observer or not. Despite her innate curiosity, her social position provided the conditions for her more disembodied natural philosophy.

84. See Harold J. Cook, Matters of Exchange: Commerce, Medicine and Science in the Dutch Golden Age (New Haven: Yale University Press, 2007).

85. To be found in Cavendish, Natures Pictures. 
Although Cavendish might have been engaged in a rather more disembodied science than Trye, she was certainly not a "disinterested scientist." ${ }^{86}$ Nor was Trye. Cavendish and Trye use their texts to represent a husband and father respectively, and to defend their capacities as female writers. Moreover, these authors take shape as individuals who seek contact with other players in the field without necessarily losing their autonomy. They prove that, rather than being outsiders and exceptions, they actively engaged in contemporary medical and philosophical debates. The picture drawn here of their different respective self-fashioning as authors clearly indicates that early modern science did not, after all, depend upon a homogenous group of objective witnesses. 